\title{
A Study on Gender Preferences and Its Sociocultural Aspects Among Married Women (18-45 Years) In Rural Gurugram
}

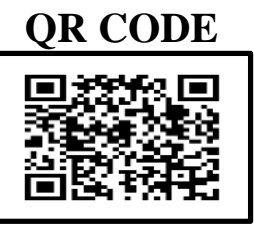

\author{
V K SINGHAL'1, SHALINI RAY², PRIYANKA SACHDEVA*2, VISHESH YADAV3
}

INTRODUCTION: Declining sex ratio is a major concern worldwide, especially in a developing country like India. The role of sociocultural factors in gender preference is known since ages. The skewed sex ratio in India is attributed to selective female feticides and misuse of technological advancements. This also has a strong influence on contraceptive acceptance among couples.

OBJECTIVES: The present study was conducted to explore the contraceptive use, gender preferences and its determinants among married women in rural Gurgaon.

MATERIALS AND METHODS: A cross-sectional study was conducted among married women (18-45years) residing in the rural field practice area of SGT medical college and hospital, Gurugram. The sample size was found to be 400 . Systematic random sampling technique was used to recruit the study participants. Pre- tested, pre-designed questionnaire was used for data collection.

RESULTS AND DISCUSSION: Among 400 married women, current contraceptive usage among study population was found to be $58.25 \%$. The most common method of contraception used by the study subjects was intrauterine contraceptive device. The preference for male child was found among $49.5 \%$ women. The reasons cited for such preference were propagation of family name ( $48.2 \%)$, financial dependability in the old age ( $34 \%$ ), social responsibilities are carried out by males $(25.3 \%)$ and males are lesser economic liability (31\%). Lower age group of mother, nulliparity, Hindu religion, lower educational status and lower socioeconomic status were found to be the determinants of male child preference in the present study. CONCLUSION: There is need of awareness and education amongst women and both the genders deserve equal respect without any preferences.

KEYWORDS: Gender Preference, Contraception, Sex Ratio

\section{INTRODUCTION}

Gender composition is an important aspect of the family, and the society at large. A balanced sex ratio plays a vital part in maintaining a stable society. Unfavourable sexratio is not unique to India. There is a strong gender preference for male child in India. ${ }^{1,2}$ The preference for sons has even led to female feticide. However, the alarming fact is that India has one of the lowest child sex ratios in the world with 914 girls /10oo boys, which has fallen from 927 girls/10oo boys in 2001. ${ }^{3}$ Various factors that can be attributed to the decline in sex-ratio include increased sex selective female abortions, and female feticide. This is now being actualized by using the technology of sonographic scans, amniotic fluid examination etc. to detect the sex of a foetus and abort female foetuses. Preference for a son has also been cited as one of the reasons for high fertility and skewed sex ratio in India and it has a powerful influence on acceptance of any contraceptive method. Changes in sex ratio reflect underlying socioeconomic and cultural patterns of a society. Not many studies have assessed the perception of women regarding their gender preferences.

\section{Objectives}

1. To explore the contraceptive use and gender preferences among married women in rural areas of
Gurugram.

2. To find the associated factors for gender preference among married women in rural areas of Gurugram.

\section{MATERIALS AND METHODS}

The present cross-sectional study was conducted among married women (18-45years) residing in the rural field practice area of SGT medical college and hospital, Gurugram. Assuming that 50\% of the rural women had a gender preference, taking $10 \%$ relative precision and $95 \%$ confidence level, the sample size was found to be 400 . Systematic random sampling method was used to recruit study subjects who gave their consent for participation. Women who had attained surgical or natural menopause were excluded. All eligible women from each selected household were taken till optimum sample size was achieved. Face to face interview was done using a pretested predesigned questionnaire. Data analysis was done using Epi info 7 software. The Chi-square test for proportion was used as test of significance. Univariate analysis was done and $p$ value of $<0.05$ was considered to be significant.

\section{RESULTS}

Majority of the study subjects i.e.50.5\% were in the age group of 18 -3oyears. More than half i.e. $53 \%$ of the study unrestricted use, distribution and reproduction in any medium, provided the use is not commercial and the original author(s) and source are cited. 
population were Hindus and $\mathbf{2 1} \%$ were Muslims. Majority of the study subjects i.e. $60.5 \%$ were living in nuclear family. It was also found that $57 \%$ of the rural married women were having secondary level education and above. The modified BG Prasad socioeconomic scale was used to assess the socioeconomic status. About $45 \%$ belonged to lower class, $36 \%$ to middle class and $19 \%$ to upper class. [Table 1]

\begin{tabular}{|c|c|c|}
\hline $\begin{array}{c}\text { Sociodemographic } \\
\text { profile } \\
\end{array}$ & Number & $\begin{array}{c}\text { Percentage } \\
(\%) \\
\end{array}$ \\
\hline \multicolumn{3}{|c|}{ AGE } \\
\hline 18-30years & 202 & 50.5 \\
\hline 31-40years & 123 & 30.75 \\
\hline >40years & 75 & 18.75 \\
\hline \multicolumn{3}{|c|}{ RELIGION } \\
\hline Hindu & 212 & 53 \\
\hline Muslim & 84 & 21 \\
\hline Christian & 12 & 03 \\
\hline Sikh and others & 92 & 23 \\
\hline \multicolumn{3}{|c|}{ TYPE OF FAMILY } \\
\hline Nuclear & & 60.5 \\
\hline Joint & & $39 \cdot 5$ \\
\hline \multicolumn{3}{|c|}{ EDUCATIONAL STATUS } \\
\hline Illiterate & 78 & $19 \cdot 5$ \\
\hline Primary & 94 & 23.5 \\
\hline Secondary & 202 & 50.5 \\
\hline $\begin{array}{c}\text { Higher secondary } \\
\text { and above }\end{array}$ & 26 & 6.5 \\
\hline \multicolumn{3}{|c|}{ SOCIOECONOMIC STATUS } \\
\hline Lower & 180 & 45 \\
\hline Middle & 144 & 36 \\
\hline Upper & 76 & 19 \\
\hline
\end{tabular}

Table 1. Sociodemographic Profile of the Study Subjects $(n=400)$

On questioning regarding current contraceptive usage, $233(58.25 \%)$ subjects were currently using some or the other method of contraception. The most common method of contraception used by the study subjects was intrauterine contraceptive device, with 83 (35.6\%) using this method. Oral contraceptive pills were used by 27 (11.6\%); condom usage was found to be present among $68(29.2 \%)$. About $47(20.2 \%)$ of the study subjects had undergone tubectomy \& only 8 (3.4\%) of study subjects reported of their husbands undergone vasectomy. [Table 2]

Majority $197(84.5 \%)$ of current contraceptive users reported of using family planning services for more than 12 months period.

\begin{tabular}{|c|c|c|}
\hline & Number & Percentage \\
\hline Male condoms & 68 & $29.2 \%$ \\
\hline Oral contraceptive & & \\
pills & 27 & $11.6 \%$ \\
\hline Copper T & 83 & $35.6 \%$ \\
\hline Tubectomy & 47 & $20.2 \%$ \\
\hline Vasectomy & 8 & $3.4 \%$ \\
\hline Table 2. Types of Contraception Used \\
\hline \multicolumn{2}{|c|}{ (Currently) (n= 233) } \\
\hline
\end{tabular}

Out of 400 women studied, $49.5 \%$ gave preference to male child (Figure 1); the major reasons for this being propagation of family name $(48.2 \%)$, financial dependability in the old age (34\%) social responsibilities are carried out by males (25.3\%) and males are lesser economic liability (31\%). (Figure 2)

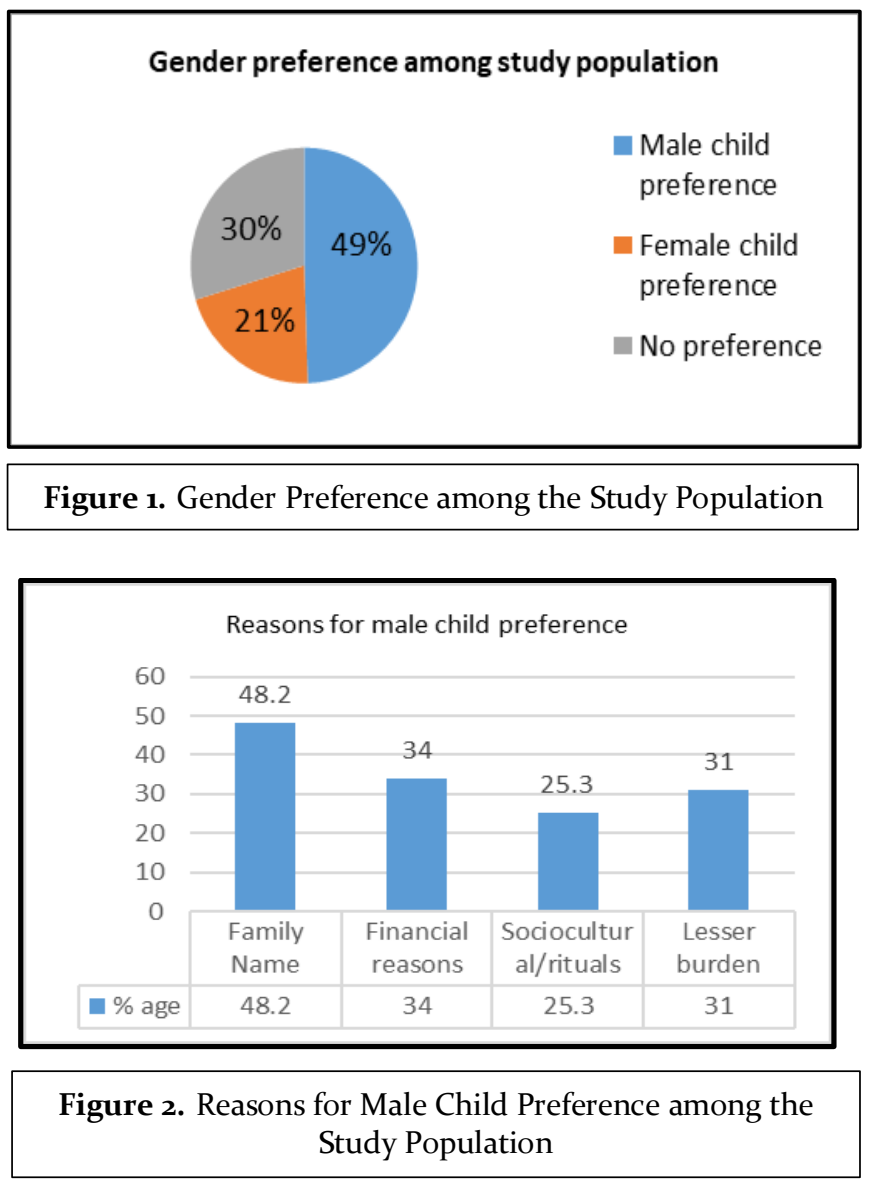

However, about $20.8 \%$ preferred female child and rest $\mathbf{2 9 . 7 \%}$ had no gender preference for child. The reasons cited for female child preference were equality between males and females $(51 \%)$, females are better caretakers $(42 \%)$ and $36 \%$ said female child completes a family. (Figure 3) 


\begin{tabular}{|c|c|c|c|c|}
\hline AGE GROUP & Male preference & $\begin{array}{c}\text { No male } \\
\text { preference }\end{array}$ & $\mathrm{X}^{2}$ value & P value \\
\hline $18-30$ & 96 & 106 & \multirow{3}{*}{10.37} & \multirow{3}{*}{0.005} \\
\hline $31-40$ & 74 & 49 & & \\
\hline$>40$ & 28 & 47 & & \\
\hline \multicolumn{5}{|c|}{ PARITY } \\
\hline Nulliparous & 84 & 27 & \multirow{3}{*}{42.19} & \multirow{3}{*}{$<0.001$} \\
\hline One child & 79 & 124 & & \\
\hline$>$ One child & 35 & 51 & & \\
\hline \multicolumn{5}{|c|}{ RELIGION } \\
\hline Hindu & 102 & 110 & \multirow{4}{*}{94.89} & \multirow{4}{*}{$<0.001$} \\
\hline Muslim & 74 & 10 & & \\
\hline Christian & 08 & 04 & & \\
\hline Sikh and others & 14 & 78 & & \\
\hline \multicolumn{5}{|c|}{ SOCIOECONOMIC STATUS } \\
\hline Lower & 86 & 94 & \multirow{3}{*}{49.41} & \multirow{3}{*}{$<0.001$} \\
\hline Middle & 98 & 46 & & \\
\hline Upper & 14 & 62 & & \\
\hline \multicolumn{5}{|c|}{ EDUCATIONAL STATUS } \\
\hline Illiterate & 59 & 19 & \multirow{4}{*}{110.6} & \multirow{4}{*}{$<0.001$} \\
\hline Primary & 78 & 16 & & \\
\hline Secondary & 54 & 148 & & \\
\hline Higher secondary & 07 & 19 & & \\
\hline TOTAL & 198 & 202 & & \\
\hline
\end{tabular}

Table 3. Determinants of Male Child Preference Among Study Population $(n=400)$

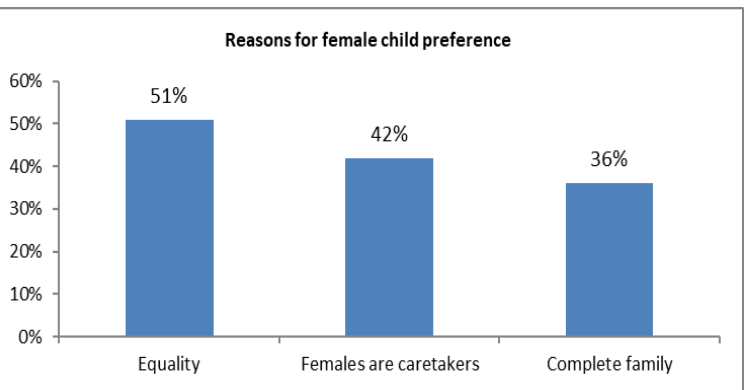

Figure 3. Reasons for Female Child Preference among the Study Population

Lower age group of mother, nulliparity, Hindu religion, lower educational status and lower socioeconomic status were found to be associated with male child preference in the study population. [Table 3]

\section{DISCUSSION}

In the present study, more than half $(50.5 \%)$ of females were in young age group 18 to 30 years. The current contraceptive usage among study population was found to be $58.25 \%$. According to NFHS $4,{ }^{4}$ the contraceptive prevalence rate in Haryana is $63.7 \%$.
The most common method of contraception used by the study subjects was intrauterine contraceptive device, with 83 (35.6\%) using this method. Oral contraceptive pills were used by 27 (11.6\%); condom usage was found to be present among $68(29.2 \%)$. About $47(20.2 \%)$ of the study subjects had undergone tubectomy \& few i.e. only $8(3.4 \%)$ of study subjects reported of their husbands undergone vasectomy.

According to DLHS $-3,{ }^{5}$ the use of contraceptive method was $47.1 \%$ using any modern method, out of which $34 \%$ used tubectomy which almost conforms to the current study while only $5.9 \%$ used condoms whereas condom usage was $29.2 \%$ in our study. However, intrauterine contraceptive devices were more preferred than condom as a spacing method in our study.

In the present study, about $49.5 \%$ gave preference to male child. Similar studies conducted by Puri et al. ${ }^{6}$ where $56 \%$ women and by Vadera et al. ${ }^{7}$ where $58.5 \%$ of the women expressed preference for a son. In the present study, the major reasons for this being propagation of family name $(48.2 \%)$, financial dependability in the old 
age $34 \%$, social responsibilities are carried out by males $(25.3 \%)$ and males are lesser economic liability (31\%).

Lower age group of mother, nulliparity, hindu religion, lower educational status and lower socioeconomic status were found to be associated with male child preference in the study population. This finding corroborates with the study done by Srivastav et al. in a district of Uttar Pradesh ${ }^{8}$ implicating the role of sociocultural factors in gender preference in India.

\section{CONCLUSION}

In the present study, male child preference is significantly associated with education, age of women, socioeconomic status, parity and religion of woman. This reflects the need of awareness and education amongst women. Both the genders deserve equal respect without any preferences. In order to achieve this, it is the need of the hour to spread awareness regarding the consequences of gender imbalance and skewed sex ratio in the society.

\section{REFERENCES}

1. Bharadwaj P, Lakdawala LK. Discrimination begins in the womb: Evidence of sex-selective prenatal investments. Journal of Human Resources. 2013;48(1):71113.
2. Dasgupta S. Son preference and gender gaps in child nutrition: does the level of female autonomy matter?. Review of Development Economics. 2016;20(2):375-86.

3. Mitra A. Son preference in India: Implications for gender development. Journal of Economic Issues. 2014;48(4):1021-37.

4. International Institute for Population Sciences, Macro International. National Family Health Survey (NFHS-4) India: Key Findings; 2015-16.

5. International Institute for Population Sciences (IIPS), 2010. District Level Household and Facility Survey (DLHS-3), 2007-08: India. Mumbai: IIPS.

6. Puri S, Bhatia V, Swami HM. Gender Preference and Awareness Regarding Sex Determination among Married Women in Slums of Chandigarh. Indian J Community Med 2007; 32: 60-2.

7. Vadera BN, Joshi UK, Unadakat SV, Yadav BS, Yadav Sudha. Study on knowledge, attitude and practices regarding gender preference and female feticide among pregnant women. Indian J Community Med 2007; 32: 300-1.

8. Shrivastava S, Kariwal P, Kapilasrami MC. A community based study on awareness and perception on gender discrimination and sex preference among married women (in reproductive age group) in a rural population of district Bareilly, Uttar Pradesh. Nat J Comm Med. 2011;2:273-6.

\section{AUTHOR AFFILIATIONS:}

